UDC 633.491-185

631.185

COBISS.SR-ID 250157836

Original research paper

Acta Agriculturae Serbica, Vol. XXII, 43 (2017); 37-46

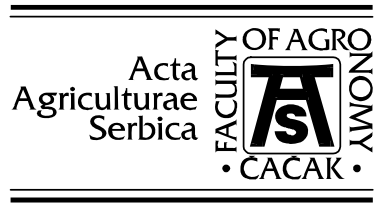

\title{
Effect of phosphorus fertilizers on yield and cadmium content of potato tubers
}

\author{
Ljiljana Bošković-Rakočević ${ }^{1}, \operatorname{Radoš~Pavlovič~}^{1}$, Milena Đurićc ${ }^{1}$ \\ ${ }^{1}$ University of Kragujevac, Faculty of Agronomy, Cara Dusana 34, 32000 \\ Čačak, Republic of Serbia \\ Corresponding author: 1jiljabr@kg.ac.rs
}

\begin{abstract}
Research was performed to determine the effect of cadmium-contaminated phosphorus fertilizers on the content of available $\mathrm{Cd}$ in the soil, its accumulation in potato tubers and potato yield. The experiment was conducted on a slightly alkaline alluvial soil containing available cadmium at a level of $0.0248 \mathrm{mg} / \mathrm{kg}$. The available $\mathrm{Cd}$ content of the soil varied with the type of phosphorus fertilizer used and the degree of its contamination with Cd, ranging from $0.0232 \mathrm{mg} / \mathrm{kg}$ on average in the treatment with the Russian monoammonium phosphate containing the lowest Cd concentration to 0.0318 $\mathrm{mg} / \mathrm{kg}$ under Bulgarian diammonium phosphate treatment. Cd concentration in potato tubers was highest under the Bulgarian diammonium phosphate $(0.092 \mathrm{mg} / \mathrm{kg})$, which contained the highest amount of $\mathrm{Cd}$, and lowest under diammonium phosphate manufactured in Russia $(0.036 \mathrm{mg} / \mathrm{kg})$. In all treatments, Cd concentrations in potato tubers were within the maximum permissible limits. The average potato yield was highest under monoammonium phosphate and lowest under triple superphosphate, and showed no dependence on the Cd contamination of fertilizers.
\end{abstract}

Key words: phosphorus fertilizers, available Cd, potato, yield

\section{Introduction}

Soil pollution with heavy metals is a serious problem in many countries worldwide. Apart from the soil parent material as the main source of heavy

Received 12 June 2017 Accepted 6 September 2017 
metals, agricultural soils are polluted with pesticides and organic and mineral fertilizers (Martin et al., 2006). Lime and superphosphate fertilizer contain not only major elements necessary for plant nutrition and growth but also trace metal impurities such as Cd. Williams and David (1973) report the Cd content of superphosphate of 38-40 mg kg $\mathrm{g}^{-1}$, Bogdanovic et al. (1999) applied superphosphate containing $2.08-7.50 \mathrm{mg} \mathrm{kg}^{-1}$, whereas Cd level in MAP was $144 \mathrm{mg} \mathrm{kg}^{-1}$ (Jiao et al., 2004). These metals can accumulate in the soil, be taken up by plants and passed on in the food chain to animals and humans (Taylor and Percival 2001). Fertilizer applications may be able to influence $\mathrm{Cd}$ speciation and complexation which affects $\mathrm{Cd}$ movement to plant root as well as Cd uptake (Wangstrand et al., 2007).

The availability of these elements to plants is governed by a number of factors such as soil $\mathrm{pH}$, clay content and organic matter content (McGrath and Cunliffe 1985; Kabata-Pendias and Pendias 2001; Golia et al., 2008). Generally, the uptake of $\mathrm{Cd}$ by plants is closely related to its concentration in soils. Cadmium concentration in vegetable crops increases with increasing $\mathrm{Cd}$ concentration in the soil (Huang et al., 20004). Most commonly, the increase in Cd levels in edible plant parts causes no toxicity symptoms, but can have deleterious effects on human health, and adverse effects on crop yield.

The objective of this study was to determine the effect of monoammonium phosphate, diammonium phosphate and triple superphosphate containing different amounts of cadmium on the yield and $\mathrm{Cd}$ content of potato tubers.

\section{Material and methods}

\section{Plant material and field trial}

A field trial was conducted in Požega ( $43^{\circ} 50^{\prime} \mathrm{N}, 20^{\circ} 02^{\prime}$ E, altitude $\left.304 \mathrm{~m}\right)$ on an alluvial soil (Table 1).

Table 1. Chemical properties of the soil

\begin{tabular}{|c|c|c|c|c|c|c|c|}
\hline \multirow{2}{*}{$\begin{array}{l}\text { Soil } \\
\text { type }\end{array}$} & \multirow[b]{2}{*}{$\mathrm{pH} / \mathrm{KCl}$} & \multirow{2}{*}{$\begin{array}{c}\mathrm{CaCO}_{3} \\
(\%)\end{array}$} & \multirow{2}{*}{$\begin{array}{c}\text { Humus } \\
(\%)\end{array}$} & \multirow{2}{*}{$\begin{array}{c}\text { Total } \\
\mathrm{N} \\
(\%)\end{array}$} & $\mathrm{P}_{2} \mathrm{O}_{5}$ & $\mathrm{~K}_{2} \mathrm{O}$ & \multirow{2}{*}{$\begin{array}{c}\text { Available } \\
\text { Cd } \\
(\mathrm{mg} / \mathrm{kg})\end{array}$} \\
\hline & & & & & \multicolumn{2}{|c|}{$(\mathrm{mg} / 100 \mathrm{~g})$} & \\
\hline Fluvisol & 7.45 & 1.7 & 2.62 & 0.181 & 61.6 & 24.3 & 0.0248 \\
\hline
\end{tabular}

The experiment involved treatment with three phosphate fertilizers i.e. monoammonium phosphate, diammonium phosphate and triple superphosphate, which contained different amounts of $\mathrm{Cd}$. The fertility of the soil used for potato production was improved by incorporating nitrogen $(120 \mathrm{kgN} / \mathrm{ha})$ and potassium $\left(180 \mathrm{kgK}_{2} \mathrm{O} / \mathrm{ha}\right)$. 
Fertilization treatments were as follows: 1. control - without fertilization; 2. DAP-Bulgarian (DAP-B) - $150 \mathrm{kgP}_{2} \mathrm{O}_{5} /$ ha; 3. DAP-Bulgarian (DAP-B) - 250 $\mathrm{kgP}_{2} \mathrm{O}_{5} /$ ha; 4. DAP-Russian (DAP-R) - $150 \mathrm{kgP}_{2} \mathrm{O}_{5} / \mathrm{ha}$; 5. DAP-Russian (DAPR) - $250 \quad \mathrm{kgP}_{2} \mathrm{O}_{5} / \mathrm{ha}$; 6. MAP-Russian (MAP-R) - $150 \quad \mathrm{kgP}_{2} \mathrm{O}_{5} / \mathrm{ha} ; 7$. MAPRussian (MAP-R) - $250 \mathrm{kgP}_{2} \mathrm{O}_{5} / \mathrm{ha}$; 8. MAP-Serbian (MAP-S) - $150 \mathrm{kgP}_{2} \mathrm{O}_{5} / \mathrm{ha}$; 9. MAP-Serbian (MAP-S) - $250 \mathrm{kgP}_{2} \mathrm{O}_{5} /$ ha; 10. TSP-Bulgarian (TSP-B) - 150 $\mathrm{kgP}_{2} \mathrm{O}_{5} /$ ha; 11. TSP-Bulgarian (TSP-B) - $250 \mathrm{kgP}_{2} \mathrm{O}_{5} / \mathrm{ha}$.

The content of $\mathrm{Cd}$ in the applied fertilizers is shown in Table 2.

Table 2. Cd content in phosphorus fertilizers

\begin{tabular}{|c|c|}
\hline Fertilizer & Cd content $(\mathrm{mg} / \mathrm{kg})$ \\
\hline DAP-B & 56.51 \\
\hline DAP-R & 0.84 \\
\hline MAP-R & 0.65 \\
\hline MAP-S & 23.69 \\
\hline TSP-B & 14.02 \\
\hline
\end{tabular}

The experiment was performed with 'Désirée', a high-yielding, medium to late maturing potato cultivar giving smooth red-skinned tubers with a light yellow flesh. During the growing season, standard cultural practices (irrigation and crop management) were used.

\section{Soil and plant chemical analysis}

Soil samples were analyzed using standard methods: the soil $\mathrm{pH}$ was measured at a 1:2.5 ratio of soil to distilled water; the humus content was determined by oxidation with $\mathrm{KMnO}_{4}$ solution (according to Kotzman); total nitrogen was assessed by Kjeldahl analysis (Gerhardt Vapodest); available phosphorus and potassium - extraction with $0.1 \mathrm{M} \mathrm{NH} \mathrm{NH}_{4}$-lactate and $0.4 \mathrm{M}$ $\mathrm{CH}_{3} \mathrm{COOH}$, according to Egner-Riehm ( $\mathrm{P}$ was analyzed spectrophotometrically by the phospho-vanadate colorimetric method and $\mathrm{K}$ was determined by flame photometry). Available $\mathrm{Cd}$ content in the soil was determined by extraction with $0.005 \mathrm{M}$ DTPA $+0.01 \mathrm{M} \mathrm{CaCl}_{2}+0.1 \mathrm{M}$ TEA solution, $\mathrm{pH}=7.3$ (Lindsay and Norvell 1978), and analyzed using atomic absorption spectroscopy (PerkinElmer, 3300/96, MHS-10).

$\mathrm{Cd}$ concentration in potato tubers was determined by digestion with $\mathrm{HNO}_{3} / \mathrm{HClO}_{4}, 5 / 1$, as described by Allen (1986). 


\section{Statistical analysis}

Results were subjected to an analysis of variance (ANOVA), and the statistical significance of differences was determined by the LSD-test $(\mathrm{P}<0.05)$, (Michigan State University, East Lansing, MI, USA).

\section{Results and discussion}

\section{Available Cd in the soil}

Prior to the establishment of the experiment, the available $\mathrm{Cd}$ content of the tested soil was $0.0248 \mathrm{mg} / \mathrm{kg}$ (Table 1). After harvesting, soil Cd levels varied with the type and rate of phosphorus fertilizer (Table 3). Soil Cd concentration decreased in treatments with DAP-R and MAP-R at both rates, but increased in the other treatments, as compared to the initial values determined before trial establishment. The low content of available $\mathrm{Cd}$ in the soil was due to its low natural levels and the alkaline soil reaction $(\mathrm{pH} / \mathrm{KCl} 7.45)$, directly causing a reduction in Cd availability in the soil (He and Singh, 1994). Another reason for the low $\mathrm{Cd}$ content of the tested alluvium was the typical absence of ionabsorbing clay minerals from the adsorption complex of this type of soil, as previously found by Bošković-Rakočević et al. (2014). Mann et al. (2002) examined the effect of phosphorus fertilizers having large amounts of $\mathrm{Cd}$ on $\mathrm{Cd}$ content in a number of soils and found that the concentration of available $\mathrm{Cd}$ in a Sandy Loam increased with increasing fertilizer application rate, but showed no increase in sandy loams regardless of high phosphorus fertilizer rates.

Table 3. Contents of available $\mathrm{Cd}$ in the soil

\begin{tabular}{|c|c|c|c|}
\hline \multirow{2}{*}{$\begin{array}{c}\text { Variants of } \\
\text { fertilization }\end{array}$} & \multicolumn{2}{|c|}{ The dose of phosphorus $(\mathrm{kg} / \mathrm{ha})$} & \multirow{2}{*}{ Average } \\
\cline { 2 - 3 } & \multicolumn{2}{|c|}{0.0248} & 250 \\
\hline Control & $0.0311^{* *}$ & $0.0325^{* *}$ & 0.0248 \\
\hline DAP-B & $0.0225^{\mathrm{ns}}$ & $0.0242^{\mathrm{ns}}$ & 0.0318 \\
\hline DAP-R & $0.0220^{\mathrm{ns}}$ & $0.0238^{\mathrm{ns}}$ & 0.0234 \\
\hline MAP-R & $0.0286^{* *}$ & $0.0306^{* *}$ & 0.0232 \\
\hline MAP-S & $0.0262^{\mathrm{ns}}$ & $0.0294^{* *}$ & 0.0296 \\
\hline TSP-B & & & 0.0278 \\
\hline
\end{tabular}
0.05
0.0031

LSD
0.01
0.0036

Both application rates of MAP-R and DAP-R led to a decrease in soil available $\mathrm{Cd}$ level relative to the control (Table 3), but no significance was 
observed. After treatment with both rates of MAP-S and DAP-B, the available Cd content of the soil increased, as compared to both the control and Russian MAP and DAP, which resulted from the incorporation of higher amounts of $\mathrm{Cd}$ through these fertilizers. A significant increase in available $\mathrm{Cd}$ level in the soil was induced by TSP-B treatment. The increase in soil available $\mathrm{Cd}$ content after MAP-S, DAP-B and TSP-B treatments were due to the higher degree of Cd contamination of these fertilizers, probably resulting from the formation of the soluble phosphate complex $\mathrm{CdHPO}_{4}$ in the soil, as previously determined by Lindsay (1979) and Krishnamurti et al. (1999). The variations in Cd content in all phosphorus fertilization treatments were induced by the different contents of $\mathrm{Cd}$ in these fertilizers, given the direct dependence of soil $\mathrm{Cd}$ content on the degree of $\mathrm{Cd}$ contamination of fertilizers (Lambert et al., 2007). Similar conclusions were previously drawn by He and Singh (1995) who found that the use of fertilizers with $\mathrm{Cd}$ rates increasing from 2.7 to $12.52 \mathrm{mg} / \mathrm{kg}$ led to an increase in available $\mathrm{Cd}$ levels in the soil. In addition, soil $\mathrm{Cd}$ content differed across treatments depending on the form of phosphate ion applied in the fertilizer used. The comparison between monoammonium phosphate and diammonium phosphate, which were similar in $\mathrm{Cd}$ content, indicates that soil $\mathrm{Cd}$ content was lower after MAP treatment, which was an expected finding, as the form of phosphorus in monoammonium phosphate is more soluble and, accordingly, more readily absorbed by plants. Levi-Minzi and Petruzzelli (1984) observed MAP effectiveness in decreasing $\mathrm{Cd}$ adsorption in the soil, particularly in soils having low organic matter levels, as in the present study.

\section{Cd concentration in potato tubers}

The concentration of $\mathrm{Cd}$ in potato tubers after phosphorus fertilization varied between $0.030 \mathrm{mg} / \mathrm{kg}$ and $0.108 \mathrm{mg} / \mathrm{kg}$ (Table 4), which was below the maximum permissible concentration of $0.3 \mathrm{mg} \mathrm{Cd} / \mathrm{kg}$ dry matter in the Republic of Serbia (Rulebook on the Levels of Pesticides, Metals and Metalloids, Official Gazette of the SRY, Issues Nos. 5/92, 11/92 Amend. 32/2002), and within the limits $(0.016-0.3 \mathrm{mg} / \mathrm{kg})$ indicated by Kabata-Pendias and Pendias (2001).

The differences in $\mathrm{Cd}$ content in potato tubers among the phosphorus fertilizers applied were directly caused by their differences in Cd content, due to which different amounts of this metal were incorporated into the soil. As compared to the control $(0.025 \mathrm{mg} / \mathrm{kg})$, the increase in Cd levels in potato tubers at both rates of MAP-R $(0.037$ and $0.042 \mathrm{mg} / \mathrm{kg})$ and DAP-R $(0.030$ and 0.042 $\mathrm{mg} / \mathrm{kg}$ ) was not significant, which was an expected result as Cd contents in the applied phosphorus fertilizers were not high. Similarly, TSP-B treatment gave no significant increase in Cd levels in potato tubers, whereas MAP-S and DAP-B, which contained significantly higher amounts of $\mathrm{Cd}$, led to a significant increase in $\mathrm{Cd}$ concentration in potato tubers. Comparable results on increased Cd levels in plants as induced by high Cd contents in the fertilizers were reported by Sterret 
et al. (1996) and He and Singh (1995). Guttormsen et al. (1995) found that increasing $\mathrm{Cd}$ rates in fertilizers caused an increase in $\mathrm{Cd}$ levels in vegetable crops, but the differences were not significant, as was the case in some treatments in the present experiment. As suggested by Mchaughlin et al. (1995), Cd concentration in potato tubers was affected by the $\mathrm{Cd}$ content of phosphorus fertilizer, but residual $\mathrm{Cd}$ in the soil was the main source of uptake of this element.

Table 4. Cd concentration in potato tubers

\begin{tabular}{|c|c|c|c|}
\hline \multirow{2}{*}{$\begin{array}{c}\text { Variants of } \\
\text { fertilization }\end{array}$} & \multicolumn{2}{|c|}{ The dose of phosphorus $(\mathrm{kg} / \mathrm{ha})$} & \multirow{2}{*}{ Average } \\
\cline { 2 - 3 } & 150 & 250 & 0.025 \\
\hline Control & \multicolumn{2}{|c|}{0.025} \\
\hline DAP-B & $0.075^{* *}$ & $0.108^{* *}$ & 0.092 \\
\hline DAP-R & $0.030^{\text {ns }}$ & $0.042^{\text {ns }}$ & 0.036 \\
\hline MAP-R & $0.037^{\text {ns }}$ & $0.047^{\text {ns }}$ & 0.044 \\
\hline MAP-S & $0.062^{* *}$ & $0.075^{* *}$ & 0.068 \\
\hline TSP-B & $0.031^{\text {ns }}$ & $0.046^{* *}$ & 0.039 \\
\hline \multicolumn{3}{|c}{0.017} \\
LSD 0.05 & 0.022 \\
\end{tabular}

Cd concentration in potato tubers significantly differed across phosphorus fertilizers (Table 4). Results showed that Cd levels in potato tubers after TSP-B treatment were lower than after MAP-R, MAP-S and DAP-B treatments and similar to the levels under DAP-R treatment regardless of the considerably higher $\mathrm{Cd}$ content in TSP-B $(14.02 \mathrm{mgCd} / \mathrm{kg})$ than in MAP-R and DAP-R. Similar results were obtained by Jiao et al. (2004) in their study on the effect of increasing rates of $\mathrm{Cd}$ in MAP and TSP, showing a higher content of $\mathrm{Cd}$ in wheat and cotton after MAP treatment than under TSP. Levi-Minzi and Petruzzelli (1984) concluded that monoammonium phosphate may increase Cd uptake by crops compared with triple superphosphate. The present research also revealed the correlation between $\mathrm{Cd}$ content in potato tubers and soil available $\mathrm{Cd}$, as previously established by Fontes et al. (2008) and Monstanas et al. (2001). Nevertheless, in conclusion, although $\mathrm{Cd}$ accumulated in potato tubers, its concentrations were within the permissible limits and, hence, the amounts of $\mathrm{Cd}$ incorporated through phosphorus fertilizers were not phytotoxic. 


\section{Potato yield}

The lowest yield of potato tubers (Table 5) was obtained in the control (39.65 $\mathrm{t} / \mathrm{ha}$ ), whereas phosphorus fertilization increased the average yield by $20.8 \%$ (TSP-B) and $41.9 \%$ (MAP-R).

Table 5. Potato yield

\begin{tabular}{|c|c|c|c|c|}
\hline \multirow{2}{*}{$\begin{array}{c}\text { Variants of } \\
\text { fertilization }\end{array}$} & \multicolumn{2}{|c|}{$\begin{array}{c}\text { The dose of phosphorus } \\
\text { (kg/ha) }\end{array}$} & \multirow{2}{*}{ Average } & Index \\
\cline { 2 - 3 } & 150 & 250 & & \\
\hline Control & \multicolumn{2}{|c|}{39.65} & 39.65 & 100 \\
\hline DAP-B & 43.20 & 55.17 & 49.18 & 124.0 \\
\hline DAP-R & 44.70 & 58.62 & 51.66 & 130.3 \\
\hline MAP-R & 50.48 & 62.06 & 56.27 & 141.9 \\
\hline MAP-S & 49.60 & 61.50 & 55.55 & 140.1 \\
\hline TSP-B & 41.38 & 54.40 & 47.89 & 120.8 \\
\hline Average & 45.87 & 58.35 & & \\
\hline
\end{tabular}

The contamination of fertilizers with $\mathrm{Cd}$ had no effect in decreasing potato yields, which was consistent with the findings of Kavvadisa et al. (2012) who found that green crop biomass increased with increasing $\mathrm{Cd}$ rates in the soil relative to the control, but only up to a certain $\mathrm{Cd}$ rate, whereas further increase in $\mathrm{Cd}$ rate caused a reduction in green crop biomass, but with no significance observed. All types of phosphorus fertilizers, regardless of the phosphorus form, increased the average yield of potato tubers at the high rate $(58.35 \mathrm{t} / \mathrm{ha})$ compared to the low rate $(45.87 \mathrm{t} / \mathrm{ha})$, as previously detemined by Lazić et al. (1998) when studying the effect of increasing fertilizer application rates on potato yield.

\section{Conclusion}

Based on the objective of the present experiment and the corresponding research, the following conclusions may be inferred:

- The available $\mathrm{Cd}$ content of the soil was directly dependent on the type of phosphorus fertilizer and its degree of $\mathrm{Cd}$ contamination, and was lowest after treatment with the Russian monoammonium phosphate which contained the lowest amount of $\mathrm{Cd}$

- $\mathrm{Cd}$ concentration in potato tubers was highest under the Bulgarian diammonium phosphate, which contained the highest level of $\mathrm{Cd}$, and lowest under Russian diammonium phosphate treatment. In all treatments, Cd concentration was within the maximum permissible limits. 
- The average yield of potato was highest under monoammonium phosphate treatment, and lowest under triple superphosphate, and showed no dependence upon the degree of $\mathrm{Cd}$ contamination of fertilizers.

\section{Acknowledgments}

This work is part of Project Ref. No. 31059 financially supported by the Ministry of Education and Science of the Republic of Serbia.

\section{References}

Allen S.E., Grimshaw H.M., Rowland A.P. (1986). Chemical analysis. In Moore PD, Chapman SB, ed. Methods in plant ecology: 285-344.

Bogdanovic, D., Ubavic, M., Cuvardic, M. (1999): Effect of phosphorus fertilization on $\mathrm{Zn}$ and $\mathrm{Cd}$ contents in soil and corn plants. Nutrient Cycling in Agroecosystems, 54: 49-56.

Bošković-Rakočević, Lj., Pavlović, R., Bogdanović, D. (2014) Effect of fertilization on available cadmium level in soils and lettuce. Acta Agriculturae Serbica, 37: 3-14.

Fontes R.L.F., Pereira J.M.N., Neves J.C.L., Fontes M.P.F. (2008): Cadmium, lead, cooper, zinc and nickel in lettuce and dry beans as related to mehlich-3 extraction in three brazilian latossols. Journal of Plant Nutrition, 31: 884901.

Golia E.E., Dimirkou A., Mitsios I.K. (2008): Influence of some soil parameters on heavy metals accumulation by vegetables grown in agricultural soils of different soil orders. Bulletin of environmental contamination and toxicology, 81: 80-84.

Guttormsen G., Singh B.R., Jeng A.S. (1995): Cadmium concentration in vegetable crops grown in a sandy soil as affected by $\mathrm{Cd}$ levels in fertilizer and soil $\mathrm{pH}$. Nutrient Cycling in Agoecosystems, 41: 27-32.

He Q.B., Singh B.R. (1994): Crop uptake of cadmium from phosphorus fertilizers: I. Yield and cadmium content. Water, Air \& Soil Pollution, 74: 251-265.

He Q.B., Singh B.R. (1995): Cadmium availability to plants as affected by repeated applications of phosphorus fertilizers. Acta Agriculturae Scandinavica, Section B-Soil \& Plant Science, 45: 22-31.

Huang B., Kuo S.,Bembenek R. (2004). Availability of cadmium in some phosphorus fertilizers to field-grown lettuce. Water, Air, \& Soil Pollution, 158: $37-$ 51.

Jiao Y., Grant C.A., Bailey L.D. (2004): Effects of phosphorus and zink fertilizer on cadmium uptake and distribution in flax and durum wheat. Journal of the Science of Food and Agriculture, 84: 777-785.

Kabata-Pendias A., Pendias H. (2001): Trace elements in soils and plants. $3^{\text {rd }}$ edition, Florida: CRC Press, Boca Ratio: 1-505.

Kavvadias V., Paschalidis C., Vavoulidou E., Petropoulos D., Koriki A. (2012): Effects of soil amended with cadmium and lead on growth, 
yield and metal accumulation and distribution in parsley. Communications in Soil Science and Plant Analysis, 43:161-175.

Krishnamurti G.S.R., Huang P.M., Kozak L.M. (1999): Sorption and desorption kinetics of cadmium from soils: influence of phosphate. Soil Science, 164: 888-898.

Lambert R., Grant C., Sauvé S. (2007): Cadmium and zinc in soil solution extracts following the application of phosphate fertilizers. Science of the Total Environment, 378: 293-305.

Lazić B., Đurovka M., Marković V., Ilin Ž. (1998): Povrtarstvo. Poljoprivredni fakultet, Univerzitet u Novom Sadu: 243-265.

Levi-Minzi R., Petruzzelli G. (1984): The influence of phosphate fertilizers on Cd solubility in soil. Water, Air \& Soil Pollution, 23: 423-429.

Lindsay W.L., Norvell W.A. (1978): Development of a DTPA soil test for zinc, iron, manganese and copper. Soil Science Society of America Journal, 42: 421-428.

Lindsay W.L. (1979): Chemical equilibria in soils. Wiley-Interscience publication, John Wiley \& Sons, New York.

Mann S.S., Rate A.W., Gilkes R.J. (2002): Cadmium accumulation in agricultural soils in western Australia. Water, Air \& Soil Pollution, 141: 281-297.

Martin J.A.R., Arias M.L., Corbi J.M.G. (2006): Heavy metals contents in agricultural topsoils in the Ebro basin (Spain). Application of the multivariate geostatistical methods to study spatial variation. Environmental Pollution, 144: 10011012.

McGrath S.P., Cunliffe C.H. (1985): A simplified method for the extraction of the metals $\mathrm{Fe}, \mathrm{Zn}, \mathrm{Cu}, \mathrm{Ni}, \mathrm{Cd}, \mathrm{Pb}, \mathrm{Cr}, \mathrm{Co}$ and $\mathrm{Mn}$ from soils and sewage sludge. The Journal of the Science of Food and Agriculture, 36: 794-798.

McLaughlin M.J., Majer N.A., Freeman K., Tiller K.G., Williams C.M.J., Smart M.K. (1995): Effect of potassic and phosphatic fertilizer type, fertilizer $\mathrm{Cd}$ concentration and zinc rate on cadmium uptake by potatoes. Nutrient Cycling in Agroecosystems, 40: 63-70.

Moustakas N.K., Akoumianakis K.A., Passam, H.C. (2001): Cadmium accumulation and its effect on yield of lettuce, radish and cucumber. Communications in Soil Science and Plant Analysis, 32: 1793-1802.

Sterrett S.B., Chaney R.L., Gifford C.H., Mielke H.W. (1996): Influence of fertilizer and sewage sludge compost on yield and heavy metal accumulation by lettuce grown in urban soil. Environmental Geochemistry and Health, 18: 135-142.

Taylor M.D., Percival H.J. (2001): Cadmium in soil solutions from a transect of soils away from a fertilizer bin. Environmental Pollution, 113(1): 35-40.

Wangstrand H., Eriksson J., Oborn I. (2007): Cadmium concentration in winter wheat as affected by nitrogen fertilization. European Journal of Agronomy, 26: 209-214.

Williams C.H., David D.J. (1973): The effect of superphosphate on the cadmium content of soils and plants. Australian Journal of Soil Research, 11: 43-56. 


\title{
UTICAJ FOSFORNIH ĐUBRIVA NA PRINOS I SADRŽAJ KADMIJUMA U KROMPIRU
}

\author{
Ljiljana Bošković-Rakočević ${ }^{1}, \operatorname{Radoš~Pavlovič~}^{1}$, Milena Đurićc ${ }^{1}$ \\ ${ }^{1}$ Univerzitet u Kragujevcu, Agronomski fakultet u Čačku, Cara Dušana 34, \\ 32000 Čačak, Srbija
}

\begin{abstract}
Rezime
Istraživanja su izvedena sa ciljem utvrđivanja uticaja kontaminiranosti pojedinih fosfornih đubriva sa kadmijumom na sadržaj pristupačnog $\mathrm{Cd} \mathrm{u}$ zemljištu, njegovu akumulaciju u krtolama krompira i prinos krompira. Ogled je izveden na zemljištu tipa aluvijum, blago alkalne reakcije, u kome je sadržaj pristupačnog kadmijuma bio $0.025 \mathrm{mg} / \mathrm{kg}$. U zavisnosti od primenjenog fosfornog đubriva $i$ kontaminiranosti tog đubriva sa $\mathrm{Cd}$ sadržaj pristupačnog $\mathrm{Cd} \mathrm{u}$ zemljištu je varirao, pri čemu je najmanji prosečni sadržaj Cd $(0.0232 \mathrm{mg} / \mathrm{kg})$ utvrđen primenom ruskog monoamonijum fosfata koji je sadržao najmanje $\mathrm{Cd}$, dok je najveći sadržaj $(0.0318 \mathrm{mg} / \mathrm{kg})$ utvrđen primenom bugarskog trostrukog superfosfata. Koncentracija Cd u krtolama krompira je bila najveća primenom bugarskog diamonijum fosfata $(0.092 \mathrm{mg} / \mathrm{kg})$, koji je imao najveći sadržaj Cd, a najmanja primenom ruskog diamonijum fosfata $(0.036 \mathrm{mg} / \mathrm{kg})$. Na svim ispitivanim varijantama koncentracija $\mathrm{Cd} \mathrm{u}$ krtolama krompira je bila u okviru maksimalno dozvoljenih vrednosti. Najveći prosečni prinos krompira ostvaren je primenom monoamonijum fosfata, a najmanji primenom trostrukog superfosfata i nije pokazivao zavisnost od kontaminiranosti đubriva sa $\mathrm{Cd}$.
\end{abstract}

Ključne reči: phosphorus fertilizers, available $\mathrm{Cd}$, potato, yield. 